\title{
Improvement of the Nutritional and Technological Quality of Rice by Steaming
}

\author{
Rasoazanakolona Voahanginirina1, Rakotonjanahary Xavier ${ }^{2}$ \\ ${ }^{1}$ Department of Technological Research, FOFIFA, National Center of Research Applied to Rural Development, Antananarivo, \\ Madagascar \\ ${ }^{2}$ Department of Rice Research, FOFIFA, National Center of Research Applied to Rural Development, Antananarivo, Madagascar \\ Email: rasoazanakolona@yahoo.fr, rakotoroland@rocketmail.com
}

How to cite this paper: Voahanginirina, $\mathrm{R}$. and Xavier, R. (2021) Improvement of the Nutritional and Technological Quality of Rice by Steaming. Open Access Library Journal, 8: e7081.

https://doi.org/10.4236/oalib.1107081

Received: December 14, 2020

Accepted: January 19, 2021

Published: January 22, 2021

Copyright (c) 2021 by author(s) and Open Access Library Inc.

This work is licensed under the Creative

Commons Attribution International

License (CC BY 4.0).

http://creativecommons.org/licenses/by/4.0/

(c) (i) Open Access

\begin{abstract}
The parboiling rice is rarely practiced technique in Madagascar, despite its many advantages. In this study, we have shown interests from the operations of our local varieties (Rojomena, red varygasy, Marisika, FOFIFA 159 "Mahasoa" (useful), FOFIFA 161 "Mahefa" (competent), FOFIFA 172) and identification of qualities offered: there was a variation in the optimal steaming time according to varieties; there was also a technological improving (as yield in whole grains, and as quick cooking food), nutritional qualities (rich in fiber higher than for plain rice); and an antioxidant enrichment (more coloring pronounced and positive phytochemical screening) was verified. In conclusion, consumption of parboiled rice is a good diet plan.
\end{abstract}

\section{Subject Areas}

Plant Science

\section{Keywords}

Parboiled Rice, Plain Rice, Morphological Quality, Technological, Nutritional, Culinary

\section{Introduction}

The Madagascan population consumes rice. It is one of the biggest consumers with $150 \mathrm{~kg} /$ inhabitant/year [1]. Each Madagascan eats almost a half kilo per day. However, this ration is doomed to an imbalance; proteins and mineral elements are often lacking in the caryopsis of rice. Poverty does not allow the purchase of protein foods generally expensive. Rice parboiling is an innovative alternation which can change the rice consumption pattern in the country. This 
technique brings an undeniable scientifically proven enrichment: by the physico-chemical analyzes of rice grains on the one hand; on the other hand, by the phenomenon osmosis dictating the passage and migration of mineral elements and proteins from the highest concentration (balls and pericarp) to the lowest one (caryopsis). Many African countries have already worked for the rural development of this technique [2].

In our study, we opted for the first alternative in order to determine the enrichment of the rice caryopsis. The purposes of the research were to strive for national food self-sufficiency, to fight against malnutrition, then to offer a better quality of rice consumed not only on the nutritional points but also on its physical aspects.

\section{Materials and Methods}

\subsection{Materials}

- Rice cooker, plastic cloth for drying.

- Memmert oven, muffle oven, desiccator

- Local red and white rice varieties: Fofifa 172, Fofifa 159, Fofifa 161, rojomena, red vary gasy, Marisika.

Rojomena is a local red irrigated rice from the middle part of the island, so is the red vary gasy, appreciated for their taste, but Marisika is white lowland rice growing at medium altitude. Its grain is easily broken and had involved improvements of its quality at shelling.

As far as the following varieties FOFIFA are concerned:

FOFIFA 159, FOFIFA 161, FOFIFA 172 are the names given by FOFIFA center to the created variety. They are all hybrids varieties and uplands rainfed rice; geographic origin: Madagascar. FOFIFA 159 (collection $n^{\circ} 4178$ ) was obtained in 2000 from parents IRAT 114 and FOFIFA 133, FOFIFA 161 (collection $n^{\circ}$ 4355) in 2003 from parents IRAT 114 and FOFIFA 133 again, and FOFIFA 172 in 2006 from parents IRAT 265 and Jumli Marshi. When the new variety reaches the farmers, they give it a new Malagasy name, such Mahasoa (useful) for FOFIFA 159, Mahefa (competent) for FOFIFA 161, but FOFIFA 172 (collection $\mathrm{n}^{\circ} 4370$ ) did not receive a new name, its experimental name is however Exp 411. The two first varieties are big round and white, if FOFIFA 172 is short round red grain. This last is a precocious rice. The two first ones are semi-precocious. FOFIFA 172 and FOFIFA 161 have sanitary aspect of grain. FOFIFA 161 was recommended until altitude $1800 \mathrm{~m}$ in southern highlands test. One advantage of FOFIFA 172 is also to adapt on highlands and to resist to several diseases. The systematic of these varieties are Plantae reign, Tracheobionta sub-reign, Magnoliophyta division, Liliopsida class, Commelinidae sub-class, Cyperal order, Poaceae family, Oryzeae tribe, Oryza L. genus, sativa species.

- Other reagents for chemical determinations: Sulfuric acid, soda, potash.

\subsection{Methods}

- Preparation of parboiled paddy. The parboiled rice was obtained according 
to the present manner: paddy had been boiled into a cooking pot during more 10 minutes, so that they reached the water content of $38 \%$. Then sample was put on a steaming pot filled of boiling water during 30 minutes; finally, the drying took place in the air under a shade which improved the quality of the machining after baking operation.

- Various mechanical treatments for the improvement of the naturally cracked Marisika variety

- Dry rice cooking test

- Chemical analysis.

- Determination of crude fiber by hot acid attack (sulfuric acid $0.3 \mathrm{~N}$ ) for 30 minutes, washing, then hot alkaline attack $(\mathrm{NaOH} 1.5 \mathrm{~N})$ during 30 minutes, followed by washing with hot water. The residue on the previously weighed filter was dried in an oven at $130^{\circ} \mathrm{C}$ for 2 hours, then cooled in the desiccator and weighed.

- Determination of alkali digestibility by incubation for 23 hours at $30^{\circ} \mathrm{C}$ with $1.7 \% \mathrm{KOH}[3]$

- Determination of total polyphenols: it was performed with the folin Ciocalteu color according to the method cited by Wong et al., 2006 [4].

- Flavonoid Dosing: The aluminum trichloride method $\left(\mathrm{AlCl}_{3}\right)$ cited by Djeridane et al., 2006 [5] was used to quantify flavonoids in these extracts.

- Phytochemical screening of phenolic compounds [6] on the extract, after methanolic extraction at hot water bath of the raw material during one hour [6], then drawing the methanol with rotavapor.

\section{Detection of flavones, flavonols, flavanones and flavanols.}

Many thousands of polyphenols have been identified in the world, among which are the flavonoïds and the tannins. Flavones, flavonols, flavanones, flavanols and anthocyanins are the flavonoids groups, the tannins groups are the polymeric forms.

The detection was carried out as follows: $200 \mathrm{mg}$ of methanolic extract were depigmented with $3 \times 10 \mathrm{ml}$ of petroleum ether and then it was dissolved in $80 \%$ ethanol. After filtration, the extract solution was subjected to the following reactions:

- Wilstater test: $1 \mathrm{ml}$ of the sample was added with $0.5 \mathrm{ml}$ of concentrated $\mathrm{HCl}$ and 3 turns of magnesium. After 10 minutes, might form three types of color: a red color indicating the presence of flavones, a purple one showing the presence of flavonols, and the appearance of a purplish red color happening for the presence of flavanones and flavanols.

- Modified Wilstater test. $1 \mathrm{ml}$ of the sample was added with $0.5 \mathrm{ml}$ of concentrated $\mathrm{HCl}$ and 3 turns of magnesium. After dissolution of the magnesium, was poured $1 \mathrm{ml}$ of water, then $1 \mathrm{ml}$ of isoamyl alcohol. After 10 minutes, it could appear a red color in case of the presence of flavones and a purple color in the presence of flavonols.

- Detection of anthocyanins: The test was carried out on the methanolic extract. $2 \mathrm{ml}$ of the extract was added with $2 \mathrm{ml}$ of $25 \%$ aqueous $\mathrm{HCl}$. A pink-red color appeared, turning into purplish blue one by the addition of 
concentrated ammonia, which showed the presence of anthocyanins.

\section{Screening of tannins and polyphenols}

It was based on the formation of colored complex and insoluble complex.

- Reactions with gelatin: $200 \mathrm{mg}$ of extract were dissolved in $15 \mathrm{ml}$ of distilled water by heating and then filtered. To the filtrate obtained were added 4 drops of $100 \%$ aqueous $\mathrm{NaCl}$ solution $(\mathrm{m} / \mathrm{v})$. The mixture was distributed into 3 test tubes:

Tube $\mathrm{n}^{\circ}$ 1: Control (Methanol extract)

Tube $n^{\circ} 2$ : addition of 5 drops of $1 \%$ aqueous gelatin solution $(\mathrm{m} / \mathrm{v})$, a precipitate indicated the presence of polyphenols.

Tube $\mathrm{n}^{\circ} 3$ : addition of 5 drops of aqueous solution of $1 \%$ salted gelatin $(1 \%$ gelatin $+10 \% \mathrm{NaCl}, 50 / 50 \mathrm{v} / \mathrm{v}$ ), a precipitate indicated the presence of tannins.

- Reaction with $\mathrm{FeCl}_{3}: 5$ drops of $\mathrm{FeCl}_{3}$ in solution of $10 \%$ methanol were added to the clear solution of the Methanol extract. A brown-green color indicated the presence of condensed tannins (catechic tannins or condensed flavanols-3, and leucoanthocyans or flavanediols-3,4) while a black blue color indicated the presence of hydrolysable tannins (gallic or ellagic tannins)

- Antioxidant activity. An in vitro test with DPPH allowed the evaluation of the antioxidant activity. It was highlighted by thin layer chromatography. The developer used was ethyl acetate/methanol ( $9 / 1 ; \mathrm{v} / \mathrm{v})$; plaque was revealed by inhibition with DPPH (2,2'diphenyl-1-picryl hydrazyl) solution, then dried at room temperature. It appeared a yellow spot on purple background.

The antioxidant capacity of the most active extracts was evaluated according to Kivrak and al 2009 [7]. Ascorbic acid was the witness. $200 \mu \mathrm{l}$ of extract with final concentration between 0.1 and $10 \mathrm{mg} / \mathrm{ml}$ was mixed into $2 \mathrm{ml}$ of methanolic solution of DPPH $0.004 \%$ with $0.221<\mathrm{DO}<0.640$ at $517 \mathrm{~nm}$. After incubation in the obscurity at room temperature, absorbance (DO) was measured by spectrophotometer.

The antioxidant activity was expressed by the ability to trap free radicals estimated by \% of DPPH discoloration in the methanol, according to the following formula: of Yoo and al 2008 [8]:

At $517 \mathrm{~nm}$, Inhibition (\%) or $\mathrm{IC} \%=\left(\mathrm{DO}_{\text {control }}-\mathrm{DO}_{\text {test }}\right) / \mathrm{DO}_{\text {control }}$

Inhibition of $50 \%$ gave by regression curve for every extract defined the extract concentration which caused $50 \%$ of loss DPPH activity. It was used to compare the antioxidant activity of the varied extracts. The extract could bring back the stable free radical DPPH to lower value than that of ascorbic acid, i.e., $\mathrm{IC}_{50}$ extract $>\mathrm{IC}_{50}$ ascorbic acid.

\section{Results}

\subsection{Morphological Aspect}

By parboiling, the whitened rice formed a darker color because of pigments moving from the husk and bran into the starchy endosperm. In this, phenolic acids with antioxidant properties are transferred to the starchy endosperm of the rice 
grain. Those phenomena explained an enrichment in antioxidant of parboiled rice.

The parboiled red grains took on darker and brighter colors and retained antioxidants and other beneficial constituents. The white grains took on also a shiny golden color (Figures 1-5), showing that the bullets of parboiled decorticated rice were easily removed.

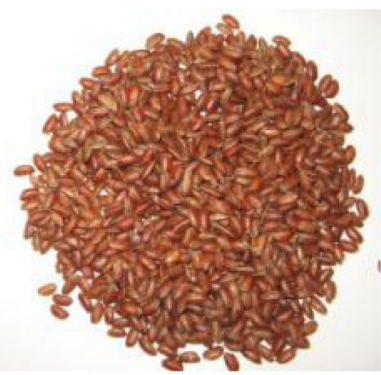

Figure 1. Parboiled FOFIFA172.

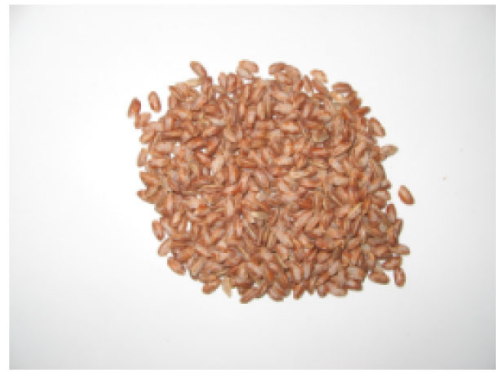

Figure 2. Plain grainsFOFIFA172.

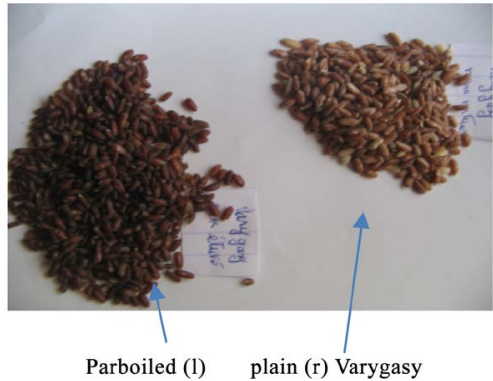

Figure 3. Parboiled (l) and plain (r) Varygasy. (l) = left; (r) = right.

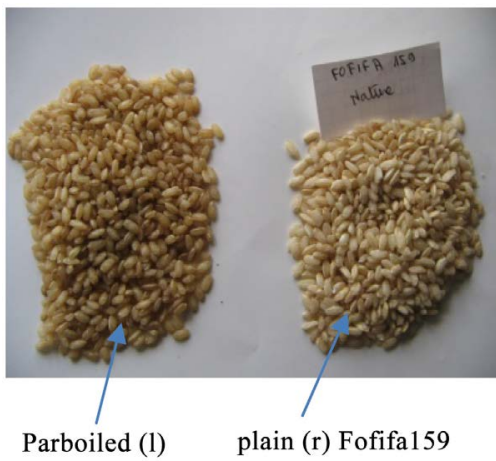

Figure 4. Parboiled (l) and plain (r) Fofifa159. (l) = left; (r) = right. 


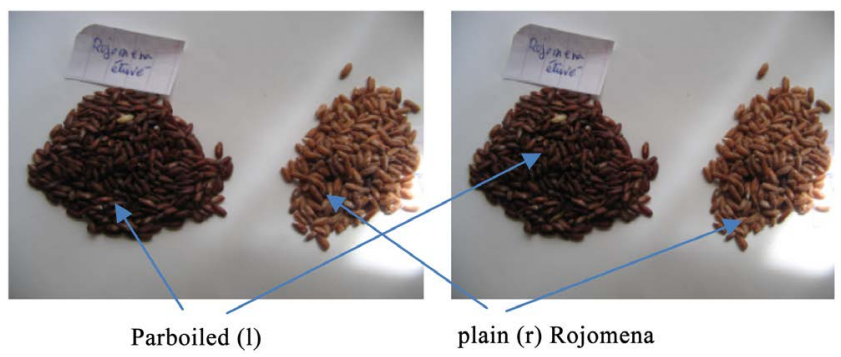

Figure 5. Parboiled (l) and plain (r) Rojomena. (l) = left; (r) = right.

\subsection{Technological Aspects}

The steaming process including a soaking operation of rice paddy into a boiling water followed by a steam cooking gave the present average results after numerous parboiling tests (Table 1 ).

There was a variation in the optimal drying time depending on the varieties: their size, their bale thickness had each a part. We could explain this variation as this: a small or thin paddy let quickly water penetrate while a thick bale took more time to let water penetrate.

- The steaming operation gave a better whole grain yield (Table 2): We found a reduced breakage

- There was a superiority in physical quality (reduction in the number of cracked grains) of parboiled grains of the Marisika variety compared to other treatments (Table 3).

\subsection{Nutritional Aspects}

- We noticed an improvement in the dietary fiber content (\%) of varieties (Table 4).

The fiber found in milled rice helps protect against digestive tract cancer and diabetes [9] [10].

- It was already also proved an enrichment in vitamins and minerals of parboiled rice: [11].

\subsection{Improvement of Culinary Quality}

Digestibility to alkali (Table 5) was generally greater with the parboiled rice varieties. This gave them quick cooking: These results were true because the parboiled whitened rice was already semi-cooked.

Better swelling grain according to dry cooking tests was also acquired with a steaming processing [2].

\subsection{Results on Polyphenols and Flavonoids Dosage (Table 6)}

Results were expressed on mean of 3 repetitions; for flavonoids, the quercetin in varied concentrations was the reference product dosed on spectrophotometer at $550 \mathrm{~nm}$, for the polyphenols, the tannic acid prepared in varied concentrations was used as reference at $765 \mathrm{~nm}$. The column 1 of Table 6 referred to the nature of the extract. 
Table 1. Optimal parboiling condition of the varieties.

\begin{tabular}{cccc}
\hline Variety & Rojomena & FOFIFA 159 & FOFIFA 172 \\
\hline Soaking in boiling water & $10 \mathrm{mn}$ & $20 \mathrm{mn}$ & $20 \mathrm{mn}$ \\
Steam cooking & $30 \mathrm{mn}$ & $30 \mathrm{mn}$ & $30 \mathrm{mn}$ \\
\hline
\end{tabular}

Table 2. Whole grain yield.

\begin{tabular}{lccccc}
\hline & Variety \\
grains & Rojomena & FOFIFA159 & FOFIFA172 & Red Varygasy & Marisika \\
\hline Plain (untreated) & $48.70 \%$ & $75.68 \%$ & $80.57 \%$ & $51.10 \%$ & $7.20 \%$ \\
Parboiled & $83.40 \%$ & $96.50 \%$ & $98.43 \%$ & $87.83 \%$ & $98.90 \%$ \\
\hline
\end{tabular}

Table 3. Number of cracked grains of Marisika per 1000 grains.

\begin{tabular}{ccccc}
\hline Paddy processing & $\begin{array}{c}\text { Paddy } 3 \text { days } \\
\text { in the sun }\end{array}$ & $\begin{array}{c}\text { Drying in } \\
\text { the shade }\end{array}$ & $\begin{array}{c}\text { Planting of } \\
\text { a non-cracked } \\
\text { grain }\end{array}$ & Parboiling \\
\hline $\begin{array}{c}\text { Average number of cracked } \\
\text { grains on } 1000 \text { grains }\end{array}$ & 605 & 453 & 576 & 11 \\
Number of repetitions & 3 & 3 & 3 & 3 \\
\hline
\end{tabular}

Table 4. Crude cellulose content.

\begin{tabular}{cccc}
\hline Variétés & FOFIFA 172 & Rojomena & FOFIFA 159 \\
\hline Crude fiber on Plain Rice & 0.40 & 0.71 & 0.87 \\
Crude fiber on Parboiled Rice & 1.04 & 1.48 & 1.05 \\
\hline
\end{tabular}

Table 5. Alkali digestibility.

\begin{tabular}{cccccc}
\hline Variety & FOFIFA161 & FOFIFA159 & FOFIFA172 & ROJOMN & Varygasy \\
\hline $\begin{array}{c}\text { Alkali Digestibility } \\
\text { on Plain Rice }\end{array}$ & 1.7 & 4.70 & 1.0 & 4.2 & 1.0 \\
$\begin{array}{c}\text { Alkali Digestibility } \\
\text { on Parboiled Rice }\end{array}$ & 7.0 & 7.0 & 4.0 & 6.0 & 5.2 \\
\hline
\end{tabular}

Table 6. Polyphenols and Flavonoids Dosage.

\begin{tabular}{|c|c|c|c|c|c|}
\hline Extract & $\begin{array}{c}\text { Total } \\
\text { flavonoids } \\
(\mu \mathrm{g} \text { in } \\
\text { quercetin } \\
\text { equivalent } / \mathrm{ml} \text { ) }\end{array}$ & $\begin{array}{c}\text { Total } \\
\text { flavonoids } \\
(\mu \mathrm{g} \text { in } \\
\text { quercetin } \\
\text { equivalent/mg) }\end{array}$ & $\begin{array}{c}\text { Total } \\
\text { polyphenols } \\
(\mu \mathrm{g} \text { in } \\
\text { tannic acid } \\
\text { equivalent } / \mathrm{ml})\end{array}$ & $\begin{array}{c}\text { Total } \\
\text { polyphenols } \\
\text { ( } \mu \mathrm{g} \text { in } \\
\text { tannic acid } \\
\text { equivalent/mg) }\end{array}$ & $\begin{array}{c}\text { Total } \\
\text { polyphenols } \\
\text { ( } \mu \mathrm{g} / \mathrm{mg} \text { in } \\
\text { gallic acid) }\end{array}$ \\
\hline $\begin{array}{l}\text { Parboiled } \\
\text { Rojomena }\end{array}$ & 14.4 & 1.53 & 867 & 310 & 34.26 \\
\hline $\begin{array}{c}\text { Parboiled } \\
\text { FOFIFA } 172\end{array}$ & 18.6 & 2.43 & 425 & 358 & 39.59 \\
\hline
\end{tabular}


Total flavonoids expressed in $\mu \mathrm{g} / \mathrm{ml}$ (column 2 on Table 6) measured at $550 \mathrm{~nm}$; total flavonoids expressed in $\mu \mathrm{g} / \mathrm{mg}$ (column 3 on Table 6) calculated values.

Total polyphenols expressed in $\mu \mathrm{g} / \mathrm{ml}$ of equivalent tannic acid (column 4 in Table 6) measured at $765 \mathrm{~nm}$; total polyphenols expressed in $\mu \mathrm{g} / \mathrm{mg}$ in equivalent tannic acid (column 5 in Table 6) calculated value; total polyphenols expressed on equivalent gallic acid in $\mu \mathrm{g} / \mathrm{mg}$ (column 6 in Table 6) calculated value, knowing that molecular weight of tannic acid is $1701.23 \mathrm{~g}$, and that of gallic acid is $188.14 \mathrm{~g}$.

The parboiled FOFIFA 172 showed a superiority in the polyphenolic class, though it had not a manifest antioxidant activity compared to the variety Rojomena. Both two (Rojomena and FOFIFA 172) had however a vegetable and a fruit polyphenolic content [12]. The parboiled Rojomena extract reflected an antioxidant activity, and it contained flavonoids $(1.53 \mu \mathrm{g} / \mathrm{mg})$ near that of artichoke stem $(1.46 \mu \mathrm{g} / \mathrm{mg})$, when the parboiled FOFIFA 172 had value $(2.43$ $\mu \mathrm{g} / \mathrm{mg})$ near that of pimento $(2.49 \mu \mathrm{g} / \mathrm{mg})$. In comparing still with literature result, the polyphenolic total content found on Rojomena extract was $34.26 \mu \mathrm{g} / \mathrm{mg}$ in gallic acid equivalent, it is was again comparable with that of artichoke stem $(34.51 \mu \mathrm{g} / \mathrm{mg}$ ), if the FOFIFA 172 extract possessed $39.59 \mu \mathrm{g} / \mathrm{mg}$ in gallic acid equivalent, near that of banana $(41.55 \mu \mathrm{g} / \mathrm{mg}$ in gallic acid equivalent). The two extracts seemed then low in polyphenols and flavonoids contents, compared with Djenidi classification [12] on vegetables and fruits analyzed.

\subsection{Results of Phytochemical Screening (Table 7)}

Among polyphenolic compounds and flavonoids present in all the rice extracts,

Table 7. Phytochemical screening.

\begin{tabular}{|c|c|c|c|}
\hline \multirow{2}{*}{$\begin{array}{c}\text { Nature of the } \\
\text { sample to } \\
\text { be tested }\end{array}$} & \multirow{2}{*}{$\begin{array}{c}\text { Present polyphenolic } \\
\text { compounds } \\
\text { Tannins and } \\
\text { polyphénols Tests }\end{array}$} & \multicolumn{2}{|c|}{ Present flavonoids } \\
\hline & & $\begin{array}{c}\text { Wilstater } \\
\text { Test }\end{array}$ & $\begin{array}{c}\text { Wilstater } \\
\text { modified Test }\end{array}$ \\
\hline FOFIFA 172 plain & Gallic tannins & Flavonol & Flavonol \\
\hline FOFIFA 172 parboiled & Gallic tannins & $\begin{array}{c}\text { Flavonone } \\
\text { or flavanonol }\end{array}$ & $\begin{array}{c}\text { Flavonone or } \\
\text { flavanonol }\end{array}$ \\
\hline Rojomena plain & Condensed tannins & flavanone & Flavanone \\
\hline Rojomena parboiled & Condensed tannins + polyphenol & $\begin{array}{c}\text { Flavonone } \\
\text { or flavanonol }\end{array}$ & $\begin{array}{c}\text { Flavonone or } \\
\text { flavanonol }\end{array}$ \\
\hline Red Vary gasy plain & Gallic tannins & Flavonol & Flavonol \\
\hline Red Vary gasy parboiled & Gallic tannins & Flavonol & Flavonol \\
\hline FOFIFA159 plain & Gallic tannins & Flavanone & Flavanone \\
\hline FOFIFA159 parboiled & Gallic tannins & $\begin{array}{l}\text { Flavononol } \\
\text { or flavanone }\end{array}$ & Flavononol \\
\hline FOFIFA161 plain & Condensed tannins & $\begin{array}{l}\text { Flavononol } \\
\text { or flavanone }\end{array}$ & Flavanone \\
\hline FOFIFA161 parboiled & Condensed tannins & $\begin{array}{l}\text { Flavononol } \\
\text { or flavanone }\end{array}$ & Flavononol \\
\hline
\end{tabular}


flavonols, reknowned as the most efficient antioxidants of flavonoids [13] were found positive in the red vary gasy and in FOFIFA 172. Even more, both the two types of tannins (gallic and condensed tannin) might be present in a same plant [14], or better, a same species with variable proportions. Vary Gasy extract was tested positive on gallic tannin, Rojomena extract on condensed tannin, a flavanol polymer which became antioxidant product after degradation [15]. Though gallic tannin exhibited antioxidant properties, this one was easily hydrolysable and might activate the plant degradation by enzyme, decreasing the antioxidation action, and conducting to a possible way for oxidation by their contents. Their percentage in food and beverages could be changed depending on technological processing and storage [16].

\subsection{Results about Antioxidant Activity of Rojomena Variety According to DPPH Methods}

The Thin Layer Chromatography revealed to the DPPH showed that only the Rojomena extract between FOFIFA 172 exhibited significant antioxidant activity. The quantification gave the following result with a spectrophotometer determination at $517 \mathrm{~nm}$.

Generally, the more the extract was concentrated, the more the inhibition was high. The inhibition of $50 \%$ of extract $\left(\mathrm{Ic}_{50}\right)$ is used to compare the different materials activity given by a regression curve logarithmic in most cases. It shows that the more the inhibition of $50 \%\left(\mathrm{Ic}_{50}\right)$ is low, the more the antioxidant activity is high. The inhibition of $50 \%$ of the DPPH for Rojomena extract $\left(\mathrm{Ic}_{50 \mathrm{rjm}}\right)$ was $7.8 \mathrm{mg} / \mathrm{ml}$ for the average of a triplicate, if for the ascorbic acid the inhibition of $50 \%$ of the DPPH ( $\mathrm{Ic}_{50 a \mathrm{acc}}$ ) found was $0.30 \mathrm{mg} / \mathrm{ml}$ for the mean value of 3 repetitions. We can say that the ascorbic acid is legibly more antioxidant. The Rojomena extract was antioxidant even low, as its Ic50 was $2 \mathrm{mg} / \mathrm{ml} \leq$ Ic50 RJM according to Djenidi classification [12]; high when Ic50 $\leq 0.8 \mathrm{mg} / \mathrm{ml}$.

The result could be expressed as an antiradical activity of the parboiled rice Rojomena and that of ascorbic acid (Table 8).

\subsection{Other Proved Advantages of Parboiling Rice}

During a storage within three years, we also remarked a greater insect resistance, and a longer shelf life favor of parboiled husked rice. Contrarily, the plain husked rice showed slight powder of caryopsis, a beginning of deterioration.

Table 8. \% Inhibition of the Rojomena extract and that of ascorbic acid.

\begin{tabular}{ccc}
\hline Conc. $(\mathrm{mg} / \mathrm{ml})$ & $\mathrm{I}_{\text {extracts }}$ & $\mathrm{I}_{\text {asc.ac. }}$ \\
\hline 0.156 & 0.18 & 53.3 \\
0.312 & 7.22 & 64.62 \\
0.625 & 6.14 & 95.85 \\
1.25 & 13.9 & 96.93 \\
2.5 & 27.8 & 97.11 \\
5 & 36.64 & 97.83 \\
\hline
\end{tabular}


The different combined treatments optimized so the end result as far as parboiled rice concerned.

\section{Conclusion}

The practice of parboiling rice offers real added value and a source of good nutrition in urban and rural areas. It makes possible to improve the nutritional well being of the population and benefits from being well known and applied within the country. For the Malagasy population who consumes a lot of rice, the deprivation of proteins and vitamins is risking; in this state, parboiled rice is really suitable. It provides not only an important nutritional supplement in vitamins, proteins and mineral elements allowing the fight against malnutrition, but also a better culinary quality. The Rojomena variety is a rich biological variety containing above all antioxidant and antiradical activity to be promoted. The improved stove technique introduced at the same time on formation that can be combined with to reduce the consumption of firewood. The parboiling process holds an important place in the economy, the health and the well-being of the population.

\section{Acknowledgements}

This research was partly realized in the CNRE (National Center for Environment) laboratory of Natural Products: the analyses concerning all polyphenols, flavonoids and antioxidant determination. We thank Mr Ralambondrahety Rahanira for having allowed us to benefit from his laboratory.

\section{Conflicts of Interest}

The authors declare no conflicts of interest regarding the publication of this paper.

\section{References}

[1] https://www.alain-barre.over-blog.com/article-madagascar-06-121773418.html

[2] Ramatou, S., Hassane, A. and Amir, S. (2012) Training Report for Rice ParBoilers, Members of Women's Groups in the River Valley, on Improved Rice Parboiling Technology, APRAO-FAO, Republic of Niger.

[3] De La Cruz, N.M. (1996) IRRI, Rice Quality Testing. Plant Breeding Department, Los Banos, 45 p.

[4] Wong, C.C., Li, H.B., Cheng, K.W. and Chen, F. (2006) A Systematic Survey of Antioxidant Activity of 30 Chinese Medicinal Plants Using the Ferric Reducing Antioxidant Power Assay. Food Chemistry, 97, 705-711.

https://doi.org/10.1016/j.foodchem.2005.05.049

[5] Djeridane, A., Yous, M., Nadjemi, B., Boutassouna, D., Stocker, P. and Vidal, N. (2006) Antioxidant Activity of Some Algerian Medicinal Plants Extracts Containing Phenolic Compounds. Food Chemistry, 97, 654-660. https://doi.org/10.1016/j.foodchem.2005.04.028

[6] Indian Ocean Commission (1990) Training Center-Practical Works of Medicinal 
Plants. FED/COI/AIRDOI Project, Antananarivo, 7, 12, 13.

[7] Kivrak, I., Duru, M.E., Öztür, M., Mercan, N. and Harmandar, M. (2009) Antioxidant, Anticholinesterase and Antimicrobial Constituents from the Essential Oil and Ethanol Extract of Salvia potentillifolia. Food Chemistry, 116, 470-479.

https://doi.org/10.1016/j.foodchem.2009.02.069

[8] Yoo, M.K., Lee, H.C., Lee, H., Moon, B.K. and Lee, Y.C. (2008) Relative Antioxidant and Cytoprotective Activities of Common Herbs. Food Chemistry, 106, 929-936. https://doi.org/10.1016/j.foodchem.2007.07.006

[9] Campos, F.G. and LogulloWaitzberg, A.G. (2005) Diet and Colorectal Cancer: Current Evidence for Etiology and Prevention. Nutricion Hospitalaria, 20, 18-25.

[10] Williams, M.T. and Hord, N.G. (2005) The Role of Dietary Factors in Cancer Prevention: Beyond Fruits and Vegetables. Nutrition in Clinical Practice, 20, 451-459. https://doi.org/10.1177/0115426505020004451

[11] Lawin, G. (2006) Analysis of the Determinants of the Adoption and Dissemination of the Improved Rice Parboiling System in the Commune of Glazoue, University of Abomey-Calavi-Diploma of Agronomist Engineer Option: Economics, Socio-Anthropology and Communication.

[12] Djenidi, H. (2019) Antioxidant and Anti-Free Radical Activity of Plant Origin Foods Consumed in the Regions of Biskra and Sétif. Thesis, Biochemistry, Faculty of Sciences of the Nature and the Life, Univ. Ferhat Abbas Sétif1, Algeria.

[13] https://fr.wikipedia.org/wiki/Flavonoïdes

[14] Bechlaghem born Boudjemai Wahiba (2016) Contribution to Phytochemical Study of Secondary Metabolites (Tannin, Flavonoids and Alkaloids) of Carlina Roots. Thesis, Natural Products Laboratory, Fac. of Sc of the Nature and the Life, Algeria.

[15] https://fr.wikipedia.org/wiki/Tanin_condensé

[16] https://www.sciencedirect.com/topics/agricultural-and-biological-sciences/hydrolys $\underline{\text { able-tannin }}$ 